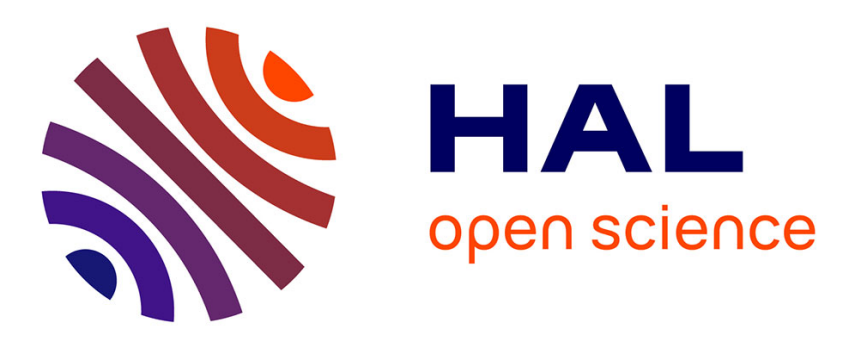

\title{
New insights into the mechanism of sorbitol transformation over an original bifunctional catalytic system.
}

Lea Vilcocq, Amandine Cabiac, Catherine Especel, Sylvie Lacombe, Daniel Duprez

\section{To cite this version:}

Lea Vilcocq, Amandine Cabiac, Catherine Especel, Sylvie Lacombe, Daniel Duprez. New insights into the mechanism of sorbitol transformation over an original bifunctional catalytic system.. Journal of Catalysis, 2014, 320, pp.16-25. 10.1016/j.jcat.2014.09.012 . hal-01138563

\section{HAL Id: hal-01138563 https://hal.science/hal-01138563}

Submitted on 2 Apr 2015

HAL is a multi-disciplinary open access archive for the deposit and dissemination of scientific research documents, whether they are published or not. The documents may come from teaching and research institutions in France or abroad, or from public or private research centers.
L'archive ouverte pluridisciplinaire HAL, est destinée au dépôt et à la diffusion de documents scientifiques de niveau recherche, publiés ou non, émanant des établissements d'enseignement et de recherche français ou étrangers, des laboratoires publics ou privés. 


\section{New insights into the mechanism of sorbitol transformation over an original bifunctional catalytic system}

\section{Léa Vilcocq ${ }^{a}$}

Amandine Cabiac ${ }^{a, *}$

amandine.cabiac@ifpen.fr

Catherine Especel

Sylvie Lacombe La $^{2}$

Daniel Duprez ${ }^{b}$

aIFP Energies nouvelles, rond-point de l'échangeur de Solaize, BP 3, 69360 Solaize, France

'Institut de Chimie des Milieux et Matériaux de Poitiers (IC2MP), UMR 7285, CNRS-Université de Poitiers, 4 rue Michel Brunet, TSA 51106, 86073 Poitiers Cedex 9, France

${ }^{*}$ Corresponding author

Abstract

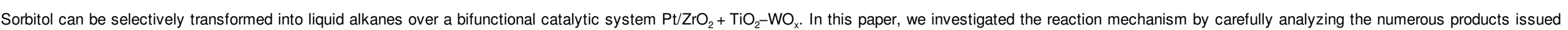

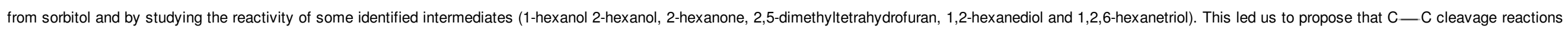

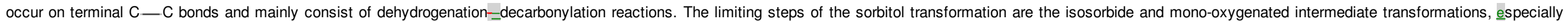

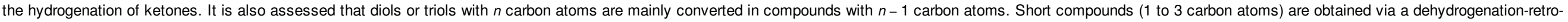
aldol reaction pathway and not from isosorbide conversion.

Keywords: Alkanes production; Biofuels; Biomass; Polyol; $\mathrm{Pt} ; \mathrm{TiO}_{2}-\mathrm{WO}_{x}$

\section{Introduction}

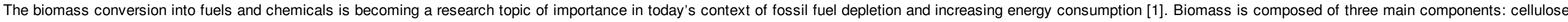

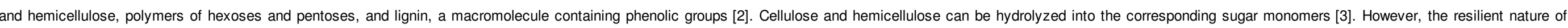

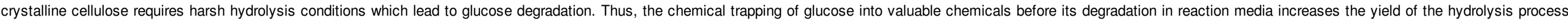

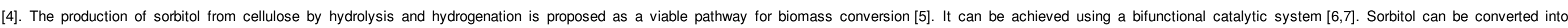

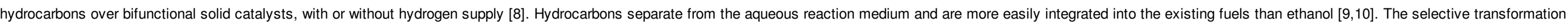
of sorbitol into hexane is however a challenge since multiple reactions occur in aqueous medium.

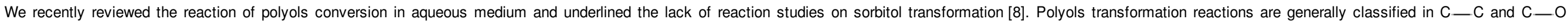

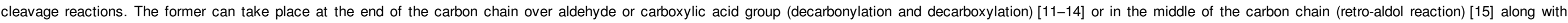

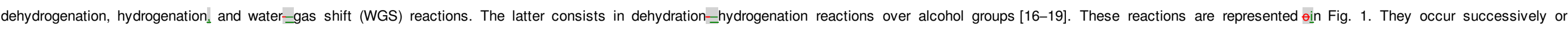

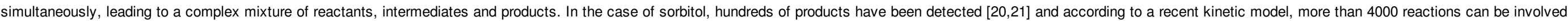
in the sorbitol reaction pathway [22] 


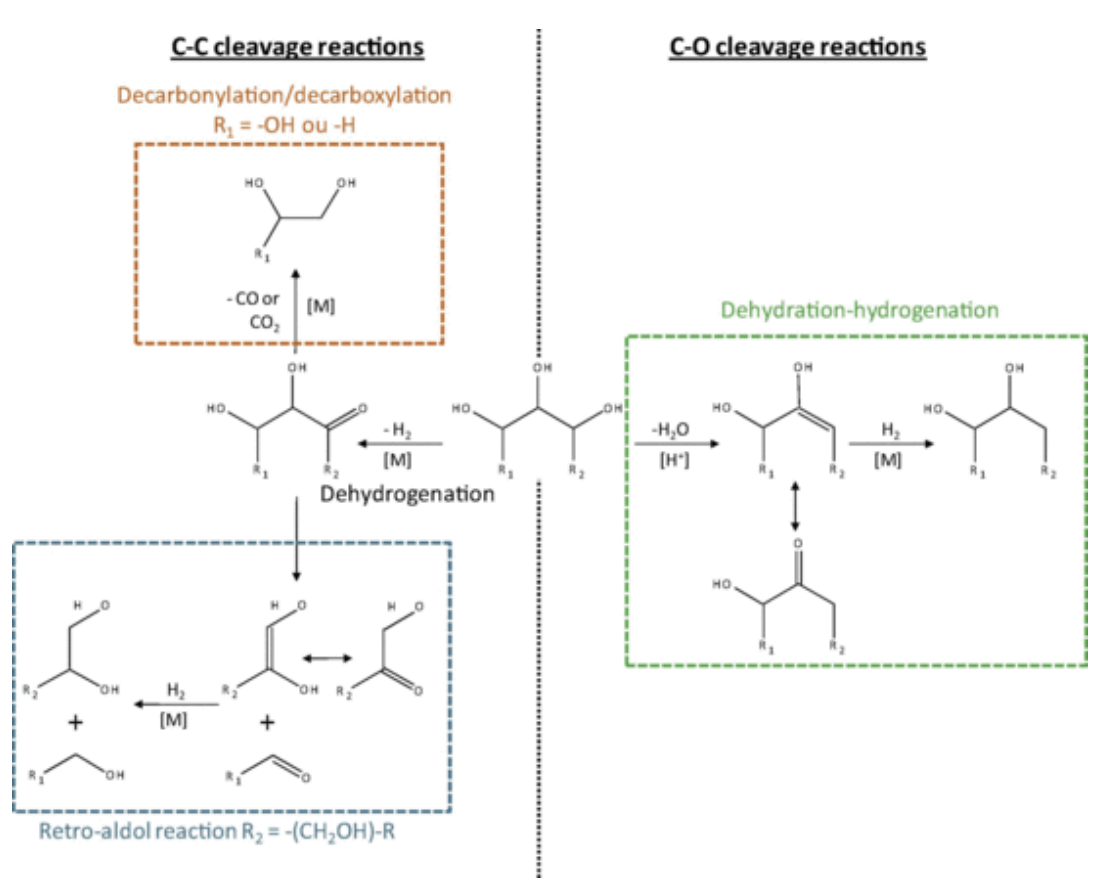

Fig. 1 Reactions involved in polyols transformation over a bifunctional catalyst.

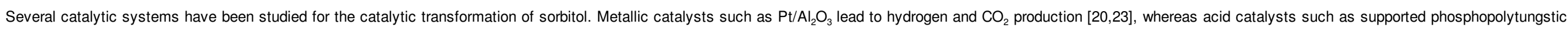

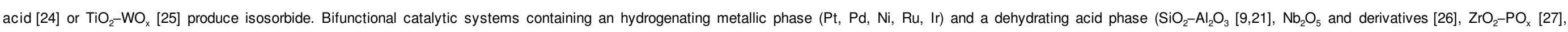

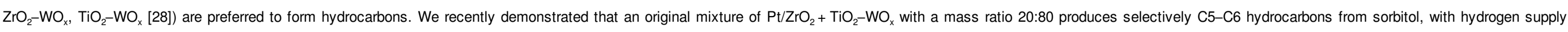

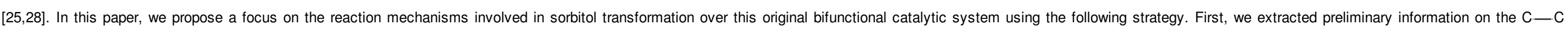

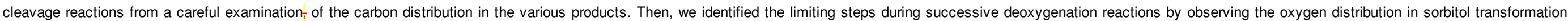
products. Finally, we explored the reactivity of some intermediates.

\section{Experimental part}

\subsection{Catalyst preparation}

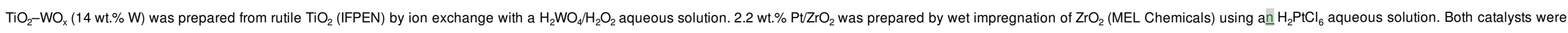
mixed to form a bifunctional catalytic system with the mass ratio $\mathrm{PtZrO}_{2}: \mathrm{TiO}_{2}-\mathrm{WO}_{\mathrm{x}}(20: 80)$. More details were given in a previous work [8].

\subsection{Catalytic tests}

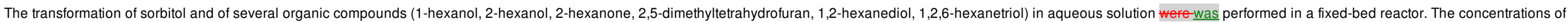

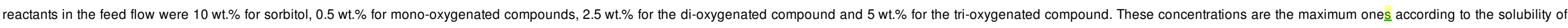
each compound.

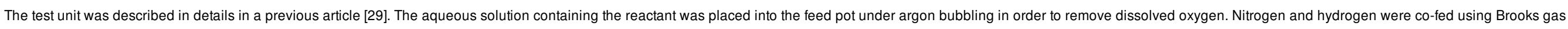

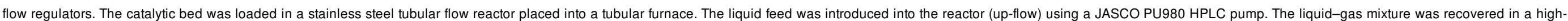




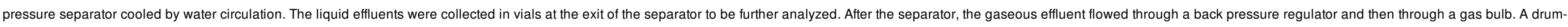

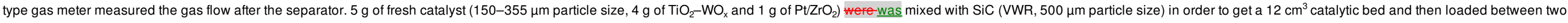

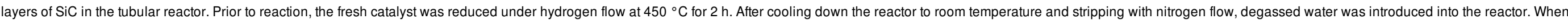

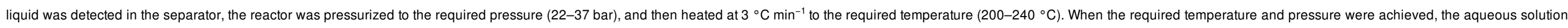
containing the reactant was co-fed with hydrogen, with a hydrogen/organic compound molar ratio equal to 25 .

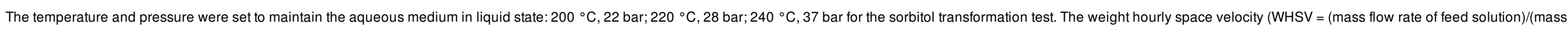

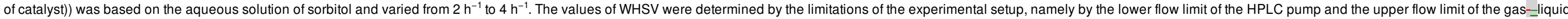

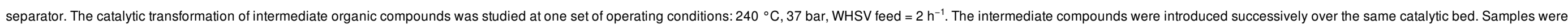
taken when the system reached equilibrium.

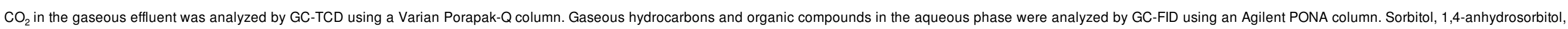
isosorbide, and 1,2,6-hexanetriol in the liquid effluent were analyzed by HPLC-RI using a Phenomenex Rezex RCM-Ca ${ }^{2+}$ column. Carbon in the aqueous phase was measured by TOC analysis on a Bioritech 1010 apparatus.

Analytical results are presented as molar yield, as follows:

$Y_{\mathrm{i}}=\frac{C_{\mathrm{i}}}{C_{\text {sorbitol }}}$

With $Y_{\mathrm{i}}$ : molar production of the compound $i\left(\mathrm{~mol} \mathrm{~mol}^{-1}\right) ; c_{\mathrm{i}}$ : concentration of $i$ detected in the effluent $\left(\mathrm{mol} \mathrm{mL}^{-1}\right) ; c_{\text {sorbitol }}$ : sorbitol concentration in the feed solution $\left(\mathrm{mol} \mathrm{mL}^{-1}\right)$.

The ratio between the number of $\mathrm{C}-\mathrm{C}$ cleavages and the number of $\mathrm{CO}_{2}$ moles $\left(R_{\mathrm{CO} 2}\right)=$ and the ratio between the number of $\mathrm{C}-\mathrm{C}$ cleavages and the number of $\mathrm{C} 1$ moles $\left(R_{\mathrm{C} 1}\right)$ are defined as follows:

$R_{\mathrm{CO} 2}=\frac{\sum Y_{\mathrm{CS}}+\sum Y_{\mathrm{C} 4} \times 2+\sum Y_{\mathrm{C}} \times 3+\sum Y_{\mathrm{C} 2} \times 4+\sum Y_{\mathrm{Cl}} \times 5}{Y_{\mathrm{CO} 2}}$

$R_{\mathrm{C} 1}=\frac{\sum \mathrm{C}_{5}+\sum Y_{\mathrm{C} 4} \times 2+\sum Y_{\mathrm{C}} \times 3+\sum Y_{\mathrm{C} 2} \times 4}{Y_{\mathrm{C} 1}}$

\section{Results}

\subsection{Products of sorbitol transformation}

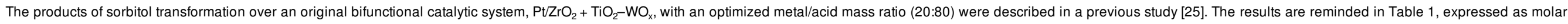

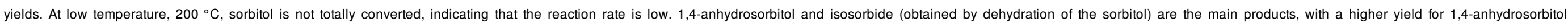

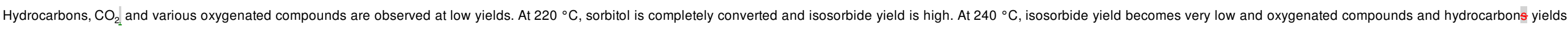
increase together with $\mathrm{CO}_{2}$ 's one. At $240^{\circ} \mathrm{C}$, when the WHSV increases from $2 \mathrm{~h}^{-1}$ to $4 \mathrm{~h}^{-1}$, the isosorbide yield increases whereas $\mathrm{CO}_{2}$ and hydrocarbons yields decrease.

Table 1 Products of sorbitol transformation over $\mathrm{Pt} / \mathrm{ZrO}_{2}+\mathrm{TiO}_{2}-\mathrm{WO}_{\mathrm{x}}$

\begin{tabular}{|c|c|c|c|c|c|}
\hline & \multirow[t]{2}{*}{ Operating conditions } & $200^{\circ} \mathrm{C}$ & $220^{\circ} \mathrm{C}$ & $240^{\circ} \mathrm{C}$ & $240^{\circ} \mathrm{C}$ \\
\hline & & 22 bar & 29 bar & 37 bar & $37 \mathrm{bar}^{\mathrm{a}}$ \\
\hline & Aqueous products & \multicolumn{4}{|c|}{ 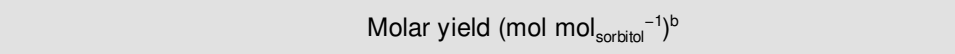 } \\
\hline \multirow[t]{2}{*}{ Polyols } & Sorbitol & 0.085 & 0 & 0 & 0 \\
\hline & Anhydrosorbitol & 0.212 & 0.085 & 0 & Traces \\
\hline
\end{tabular}




\begin{tabular}{|c|c|c|c|c|c|}
\hline & Isosorbide & 0.062 & 0.338 & 0.014 & 0.033 \\
\hline & 1,2,6-Hexanetriol & Traces & 0 & 0 & 0 \\
\hline & 1,2,4-Butanetriol & Traces & Traces & 0 & Traces \\
\hline \multirow[t]{13}{*}{ Alcohols } & Methanol & Traces & 0.009 & 0.017 & 0.013 \\
\hline & Ethanol & 0.005 & 0.012 & 0.043 & 0.014 \\
\hline & 1-Propanol & Traces & 0.011 & 0.037 & 0.012 \\
\hline & 2-Propanol & Traces & Traces & Traces & Traces \\
\hline & 1-Butanol & Traces & 0.007 & 0.024 & 0.007 \\
\hline & 2-Butanol & Traces & Traces & Traces & Traces \\
\hline & 1-Pentanol & 0.013 & 0.040 & 0.056 & 0.051 \\
\hline & 2-Pentanol & Traces & Traces & Traces & Traces \\
\hline & 1-Hexanol & 0.008 & 0.018 & 0.036 & 0.021 \\
\hline & 2-Hexanol & Traces & Traces & Traces & 0 \\
\hline & 3-Hexanol & Traces & Traces & Traces & Traces \\
\hline & 2-Methylpentanol & Traces & Traces & Traces & Traces \\
\hline & 2-Methylcyclopentanol & Traces & Traces & Traces & Traces \\
\hline Total alcohols & & 0.042 & 0.111 & 0.227 & 0.123 \\
\hline \multirow[t]{7}{*}{ Ketones } & Acetone & Traces & 0.012 & 0.007 & 0.011 \\
\hline & Butanone & Traces & 0.019 & 0.007 & 0.014 \\
\hline & 2-Pentanone & Traces & 0.022 & 0.010 & 0.017 \\
\hline & 3-Pentanone & 0.006 & 0.040 & 0.018 & 0.034 \\
\hline & 2-Hexanone & 0.012 & 0.039 & 0.025 & 0.031 \\
\hline & 3-Hexanone & 0.012 & 0.052 & 0.052 & 0.052 \\
\hline & 2-Methylcyclopentanone & Traces & 0.016 & 0.004 & 0.021 \\
\hline Total ketones & & 0.0453 & 0.2009 & 0.1244 & 0.1810 \\
\hline \multirow[t]{7}{*}{ Heterocycles } & Tetrahydrofuran & Traces & Traces & 0.007 & Traces \\
\hline & 2-Methyltetrahydrofuran & Traces & Traces & 0.008 & 0.006 \\
\hline & 2-Methylfuran & 0 & 0 & Traces & 0 \\
\hline & 2,4-Dimethyltetrahydrofuran & Traces & Traces & Traces & Traces \\
\hline & 2,5-Dimethylfuran & 0 & 0 & 0 & Traces \\
\hline & 2,5-Dimethyltetrahydrofuran & Traces & Traces & Traces & Traces \\
\hline & 5-Methyltetrahydrofuran-2-Methanol & 0 & 0 & Traces & Traces \\
\hline
\end{tabular}




\begin{tabular}{|c|c|c|c|c|c|}
\hline & 2,4-Dimethylbutyrolactone & 0 & 0 & Traces & 0 \\
\hline & Tetrahydropyran-2-methanol & Traces & Traces & Traces & Traces \\
\hline & 2-Methyltetrahydropyran & Traces & 0.007 & 0.012 & 0.007 \\
\hline Total heterocycles & & 0.007 & 0.016 & 0.034 & 0.018 \\
\hline \multirow[t]{6}{*}{ Carboxylic acids } & Formic acid & 0 & 0 & 0.012 & 0 \\
\hline & Acetic acid & 0 & 0 & Traces & 0.009 \\
\hline & Propanoic acid & Traces & 0.007 & 0.010 & Traces \\
\hline & Butanoic acid & 0 & Traces & 0 & 0.004 \\
\hline & Pentanoic acid & Traces & 0.007 & 0 & 0.007 \\
\hline & Hexanoic acid & Traces & 0.006 & 0 & 0.008 \\
\hline Total carboxylic acids & & 0.003 & 0.022 & 0.025 & 0.029 \\
\hline \multirow[t]{6}{*}{ Diols } & Ethylene glycol & Traces & Traces & 0 & 0 \\
\hline & 1,2-Propanediol & Traces & 0.001 & Traces & Traces \\
\hline & 1,2-Butanediol & Traces & 0 & Traces & Traces \\
\hline & 2,3-Butanediol & 0 & 0 & Traces & Traces \\
\hline & 1,2-Pentanediol & Traces & Traces & 0 & Traces \\
\hline & 1,2-Hexanediol & Traces & Traces & 0 & 0 \\
\hline \multirow[t]{2}{*}{ Diones } & 2,3-Pentanedione & Traces & Traces & 0 & Traces \\
\hline & 3,4-Hexanedione & Traces & Traces & Traces & Traces \\
\hline \multirow[t]{4}{*}{ Total di-oxygenated } & & 0.011 & 0.010 & 0.002 & 0.008 \\
\hline & & $200{ }^{\circ} \mathrm{C}$ & $220^{\circ} \mathrm{C}$ & $240^{\circ} \mathrm{C}$ & $240^{\circ} \mathrm{C}$ \\
\hline & Operating conditions & 22 bar & 29 bar & 37 bar & 37 bara $^{\mathrm{a}}$ \\
\hline & Gaseous products & \multicolumn{4}{|c|}{ Molar yield $\left(\mathrm{mol} \mathrm{mol}_{\text {sorbitol }}{ }^{-1}\right)$} \\
\hline \multirow[t]{6}{*}{ n-Alkanes } & Methane & Traces & 0.015 & 0.028 & 0.018 \\
\hline & Ethane & Traces & 0.016 & 0.039 & 0.025 \\
\hline & Propane & Traces & 0.016 & 0.035 & 0.019 \\
\hline & $N$-butane & 0.008 & 0.030 & 0.047 & 0.032 \\
\hline & $\underline{n-n}$-Pentane & 0.008 & 0.030 & 0.062 & 0.039 \\
\hline & $\underline{n}$-n-Hexane & 0.016 & 0.042 & 0.069 & 0.058 \\
\hline Other hydrocarbons & Iso-butane & 0 & Traces & Traces & Traces \\
\hline
\end{tabular}




\begin{tabular}{|c|c|c|c|c|c|}
\hline & Trans-2-butene & 0 & Traces & 0 & Traces \\
\hline & Cis-2-butene & 0 & Traces & Traces & Traces \\
\hline & Cyclopentane & Traces & Traces & Traces & 0.006 \\
\hline & 1-Pentene & Traces & Traces & Traces & Traces \\
\hline & Trans-2-pentene & Traces & Traces & Traces & Traces \\
\hline & Cis-2-pentene & 0 & Traces & Traces & Traces \\
\hline & 1-Methylcyclopentane & Traces & Traces & 0.007 & 0.008 \\
\hline & 1-Methylcyclopenteane & Traces & Traces & Traces & Traces \\
\hline & 2-Hexene & Traces & Traces & Traces & Traces \\
\hline & Cyclohexane & Traces & Traces & Traces & Traces \\
\hline Total hydrocarbons & & 0.050 & 0.162 & 0.295 & 0.218 \\
\hline $\mathrm{CO}_{2}$ & & 0.064 & 0.293 & 0.613 & 0.277 \\
\hline
\end{tabular}

a WHSV $=4 \mathrm{~h}^{-1}$.

b Traces: the compound is detected but its amount is lower than $0.005 \mathrm{~mol} \mathrm{~mol}^{-1}$.

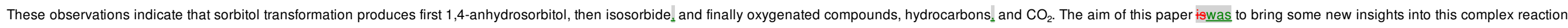
scheme.

\section{2 $\mathrm{C}-\mathrm{C}$ cleavages}

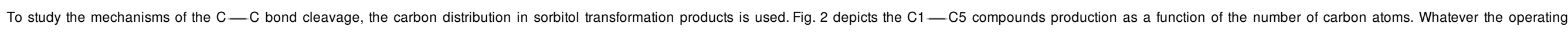

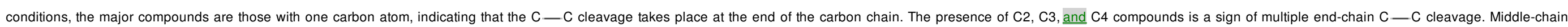

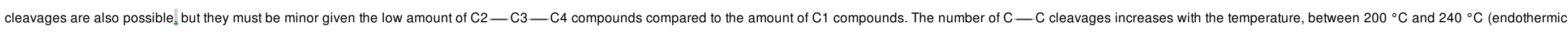

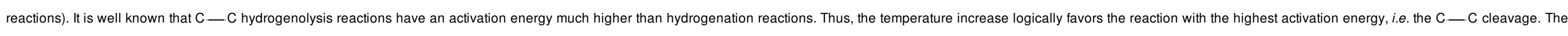
number of $\mathrm{C}-\mathrm{C}$ cleavages also increases when the WHSV decreases from $4 \mathrm{~h}^{-1}$ to $2 \mathrm{~h}^{-1}$. 


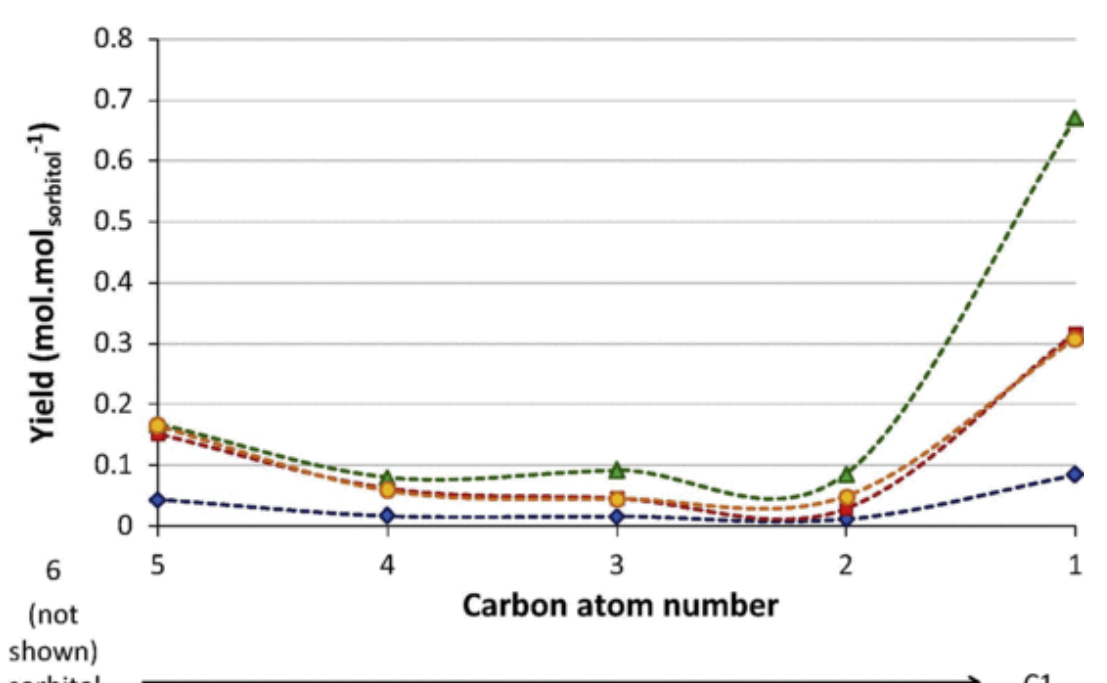

shown

sorbitol

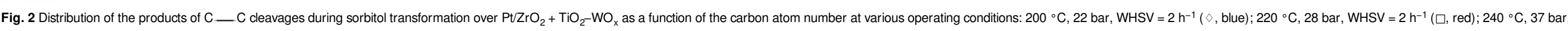

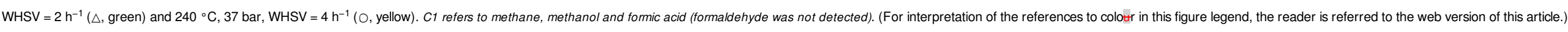

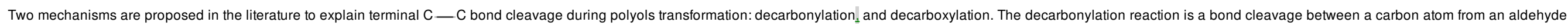

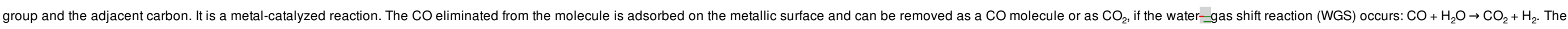

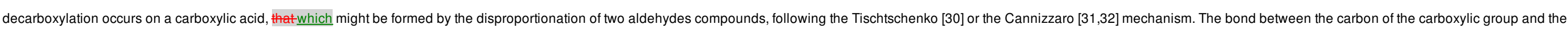
adjacent carbon is cleaved and a $\mathrm{CO}_{2}$ molecule is eliminated (Fig. 3).

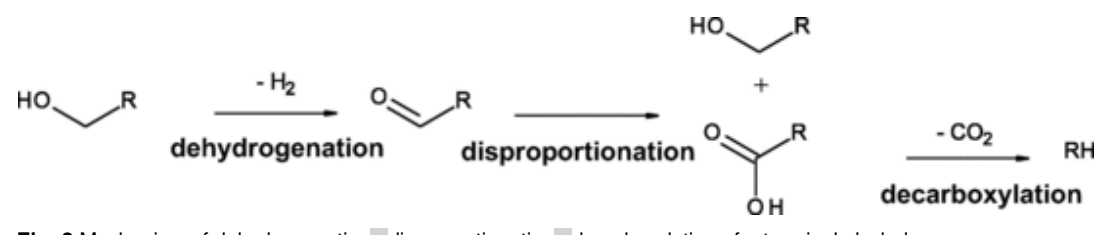

Fig. 3 Mechanism of dehydrogenation-disproportionation-decarboxylation of a terminal alcoho

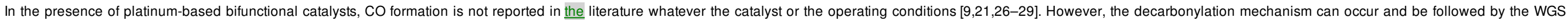
reaction: Pt is known as an efficient catalyst for WGS, and the aqueous medium shifts the reaction equilibrium to the production of $\mathrm{CO}_{2}$ and $\mathrm{H}_{2}$.

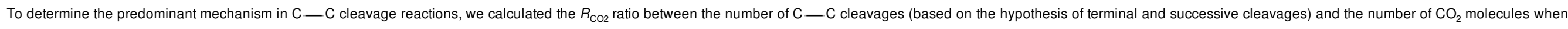

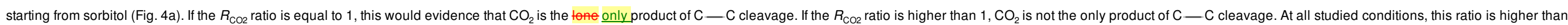

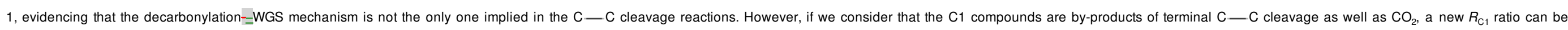

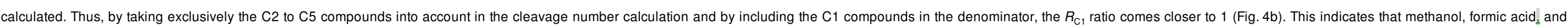

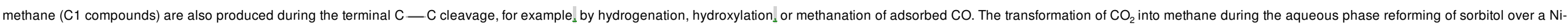
$\mathrm{Pd} / \mathrm{Al}_{2} \mathrm{O}_{3}$ catalyst was recently evidenced [33]. 

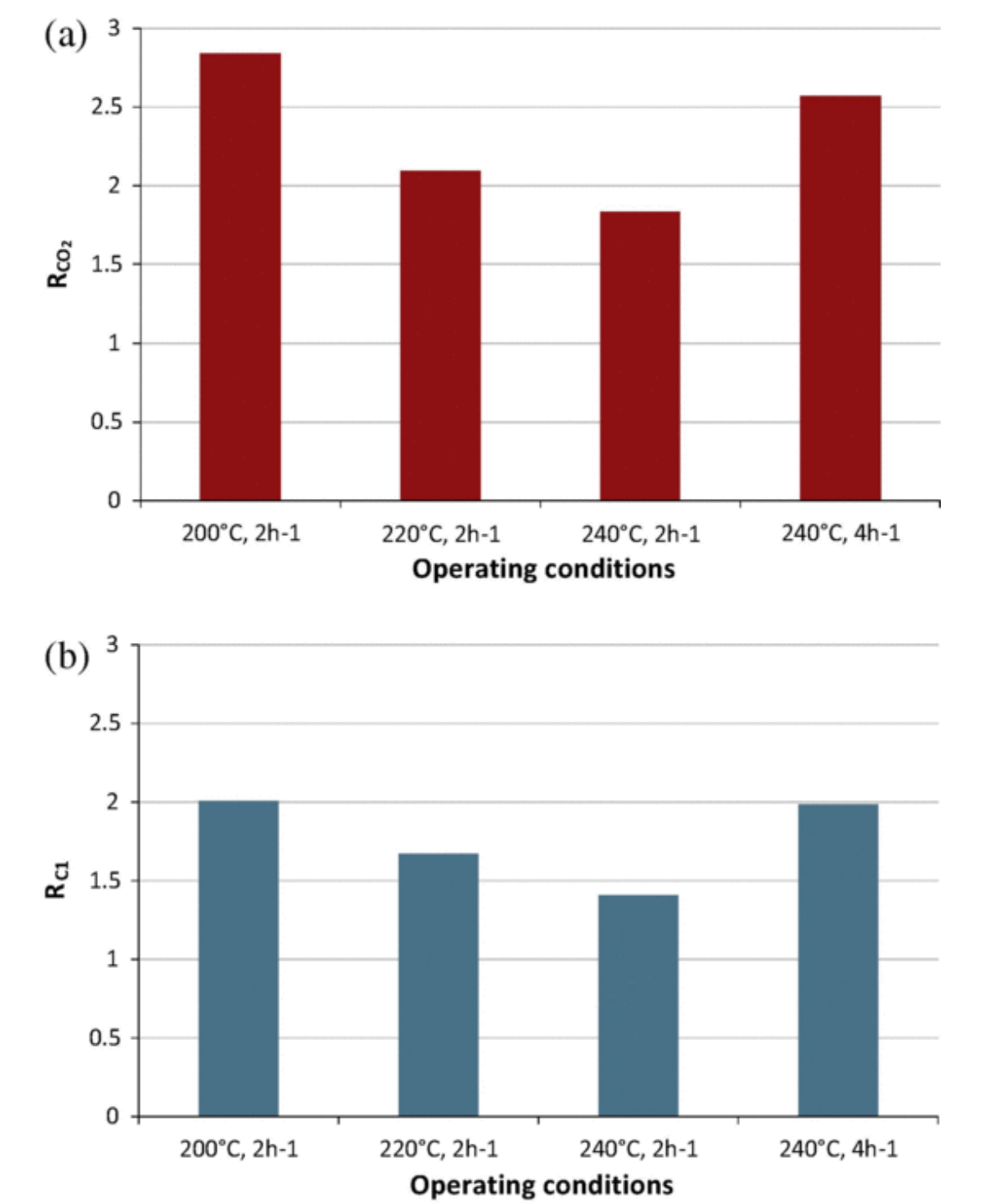

Fig. 4 Ratio of $\mathrm{C}-\mathrm{C}$ cleavage number over the amount of $\mathrm{CO}_{2}\left(R_{\mathrm{CO} 2}\right)(\mathrm{a})$ and over the amount of $\mathrm{C} 1$ compounds $\left(R_{\mathrm{C} 1}\right)(\mathrm{b})$.

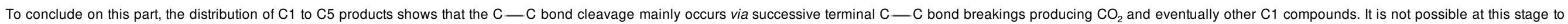
conclude on the $\mathrm{C}-\mathrm{C}$ cleavage mechanism. It is suggested in the literature that decarbonylation and decarboxylation can be present as competitive mechanisms for the aldehydes transformation [14].

\section{3 $\mathrm{C}-\mathrm{O}$ cleavages}

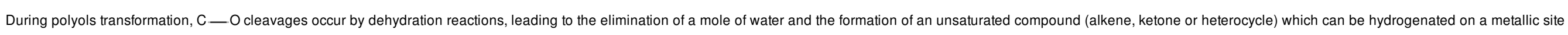

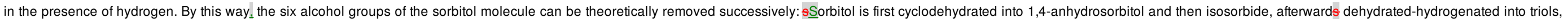

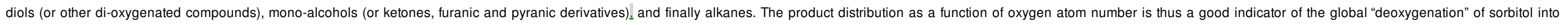




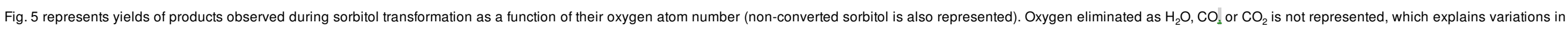

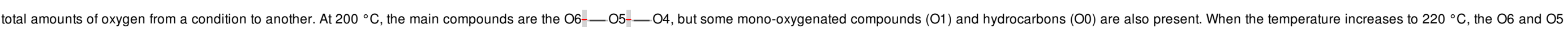

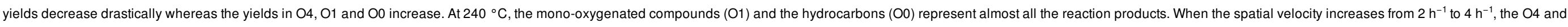

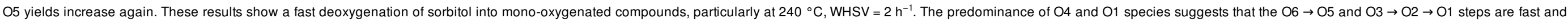
not critical for the kinetics of the overall transformation of sorbitol into hydrocarbons, whereas the conversion of mono-oxygenated compounds (O1) into hydrocarbons is one of the limiting steps of the reaction.

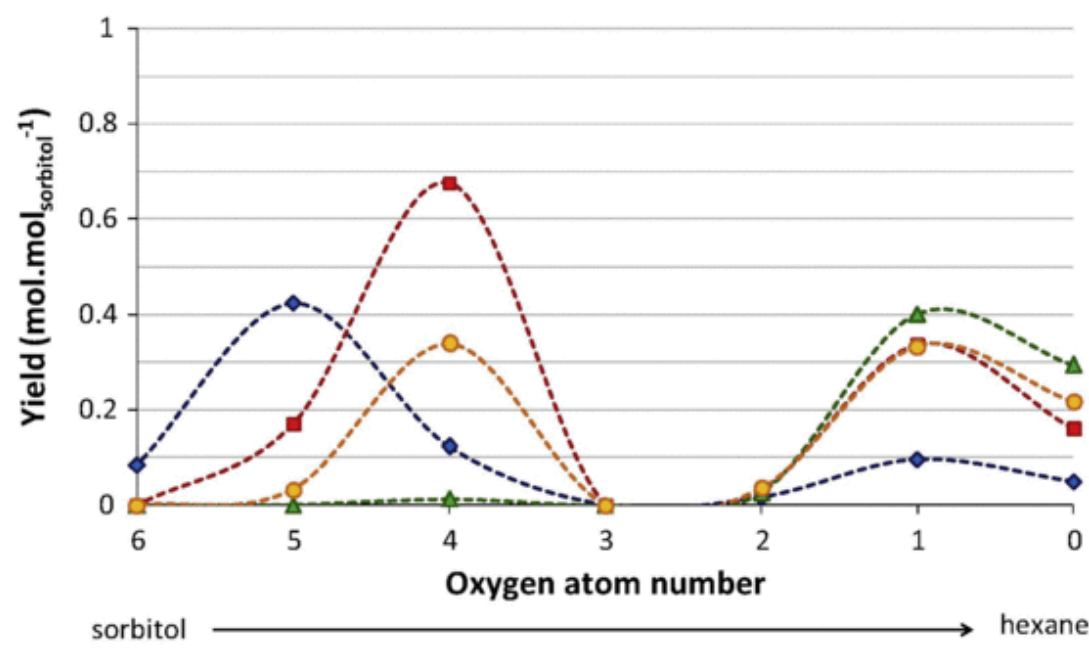

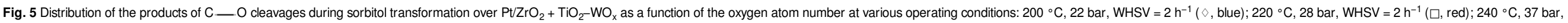
WHSV $=2 \mathrm{~h}^{-1}\left(\triangle\right.$, green) and $240{ }^{\circ} \mathrm{C}, 37 \mathrm{bar}, \mathrm{WHSV}=4 \mathrm{~h}^{-1}\left(\mathrm{O}\right.$, yellow). $\mathrm{CO}_{2}$ and $\mathrm{H}_{2} \mathrm{O}$ are not represented. (For interpretation of the references to coloutr in this figure legend, the reader is referred to the web version of this article.)

\subsection{Reactivity of intermediates}

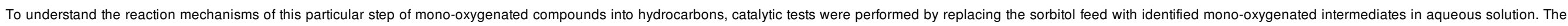

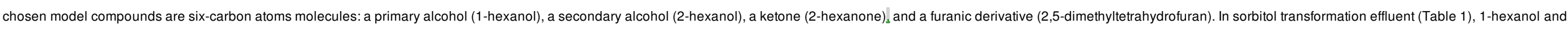
1-pentanol are the major alcohols and secondary alcohols are present as minor products, whatever the operating conditions. 2-and 3-hexanones are also major products in the aqueous phase.

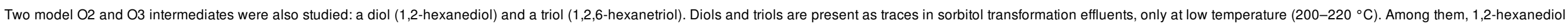
and 1,2,6-hexanetriol are the main products. The reactivity of intermediates was studied at $240^{\circ} \mathrm{C}, \mathrm{WHSV}=2 \mathrm{~h}^{-1}$.

Even if isosorbide and 1,4-anhydrosorbitol were identified as true intermediates of the sorbitol transformation, their transformation is not studied in the present paper in order to focus on the reactivity of less oxygenated compounds.

\subsubsection{Mono-oxygenated intermediates}

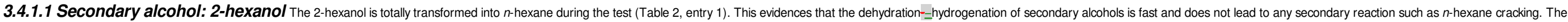
cyclodehydration of 2-hexanol is theoretically possible but was not observed.

Table 2 Products observed during the transformation of various intermediates compounds over $\mathrm{Pt} / \mathrm{ZrO}_{2}+\mathrm{TiO}_{2}-\mathrm{WO}_{\mathrm{x}}$.

Reactant Conversion (\%) Products (yield, $\left.\mathrm{mol} \mathrm{mol}_{\text {reactant }}^{-1}\right)$




\begin{tabular}{|c|c|c|c|c|c|c|c|c|c|c|c|}
\hline & & & 2,5-diMeTHF & 2-Hexanone & 2-Hexanol & 1-Hexanol & 1-Pentanol & $\underline{n-n-C 6}$ & $\underline{n-n-C 5}$ & $\underline{n-\mathrm{C}} 4$ & $\mathrm{CO}_{2}$ \\
\hline 1. & 2-Hexanol & 100 & - & - & 0 & 0 & 0 & 1.00 & 0 & 0 & 0 \\
\hline 2. & 1-Hexanol & 100 & - & - & - & 0 & 0 & 0.31 & 0.69 & 0 & 0.45 \\
\hline 3. & 2-Hexanone & 43 & - & 0.57 & Traces & 0 & 0 & 0.40 & 0 & 0 & 0 \\
\hline 4. & 2,5-diMeTHF & 58 & 0.42 & Traces & Traces & 0 & 0 & 0.55 & 0 & 0 & 0 \\
\hline 5. & 1,2-hexanediol & 100 & 0 & 0 & 0 & traces & traces & 0.21 & 0.51 & 0.20 & 0.68 \\
\hline 6. & 1,2,6-Hexanetriol & 100 & 0 & 0 & 0 & 0.06 & 0.18 & 0.14 & 0.34 & 0.22 & 0.62 \\
\hline
\end{tabular}

Traces: the compound is detected but its amount is lower than $0.05 \mathrm{~mol} \mathrm{~mol}^{-1}$.

Operating conditions: $240^{\circ} \mathrm{C}, 37$ bar, WHSV $=2 \mathrm{~h}^{-1}$.

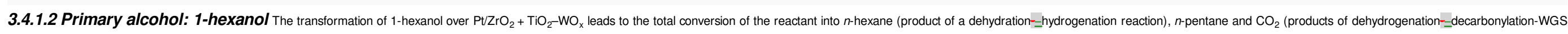
reaction) (Table 2, entry 2). The molar ratio between $n$-hexane and $n$-pentane is 0.44 , which means that in the studied conditions, the dehydration=-hydrogenation reaction is disfavored over the dehydrogenation=-decarbonylation one.

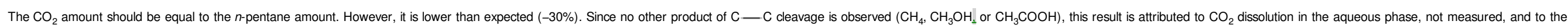
experimental error. $\mathrm{CO}$ is not analyzed.

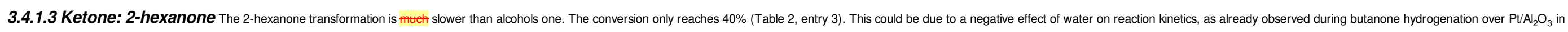

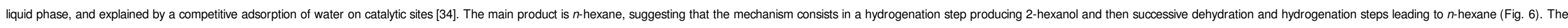
first hydrogenation is the slowest step since 2-hexanol is observed only as a trace in the effluent.

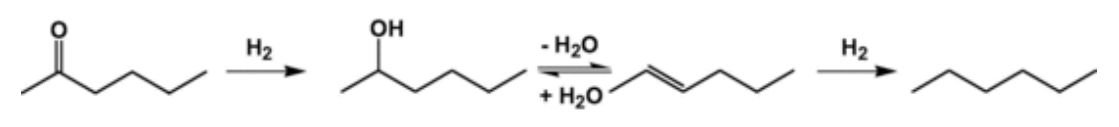

Fig. 6 Reaction scheme of 2-hexanone conversion into $n$-hexane over a bifunctional catalyst.

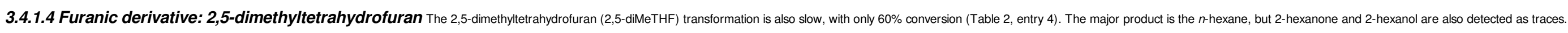

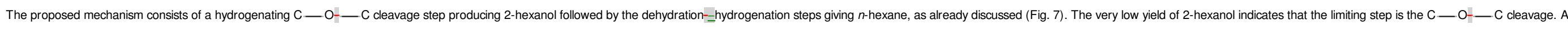
few amount of 2-hexanone is also observed. It is proposed that 2-hexanone is formed by C-O cleavage of the heterocycle, in parallel to the 2-hexanol formation (Fig. 7).

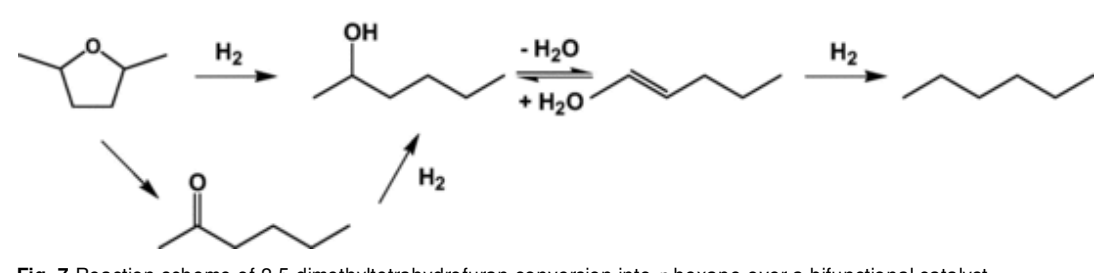

Fig. 7 Reaction scheme of 2,5-dimethyltetrahydrofuran conversion into $n$-hexane over a bifunctional catalyst.

\subsubsection{Other intermediates}

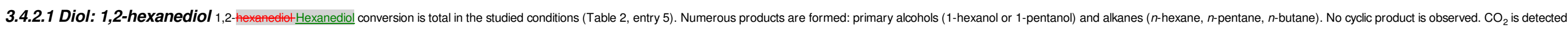
in concentrations lower than expected, as already discussed (see Section 3.4.1.2). Alkanes are the main products of the reaction, with a hexane/pentane molar ratio of 0.4.

Secondary alcohols are not detected. Most probably, they are formed and dehydrated-=hydrogenated very quickly. Alcohol group in position 1 is thus the most difficult to dehydrate during the diol transformation.

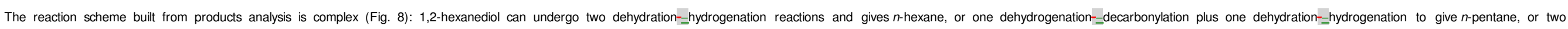




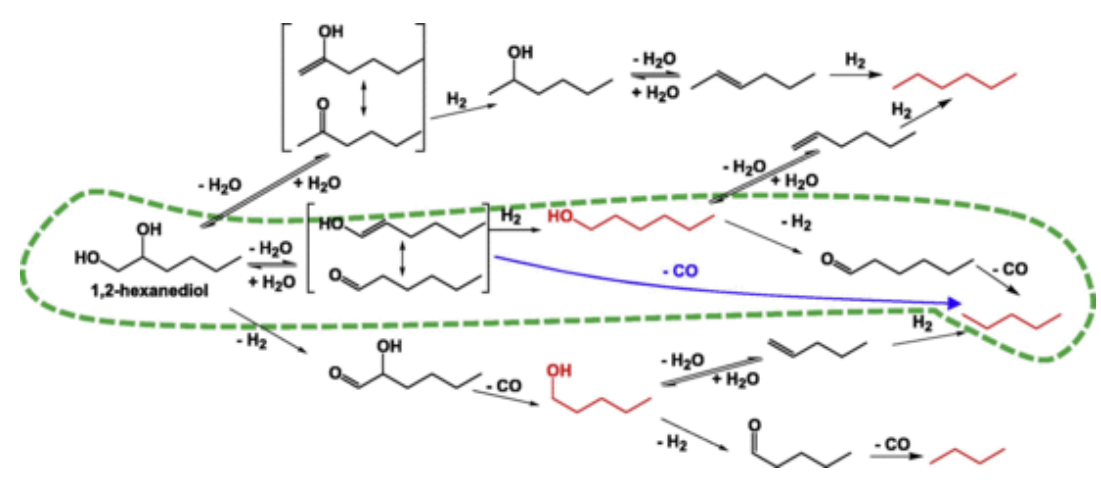

Fig. 8 Reaction scheme of 1,2 -hexanediol transformation over $\mathrm{Pt}_{2} / \mathrm{ZrO}_{2}+\mathrm{TiO}_{2}-\mathrm{WO}$

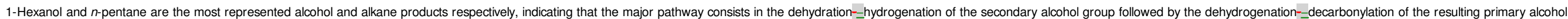

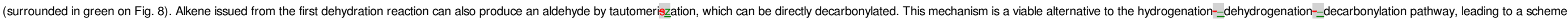
where 1 -hexanol is not an intermediate. However, this alcohol is detected in the reaction mixture, meaning that this alternative pathway is not the major one.

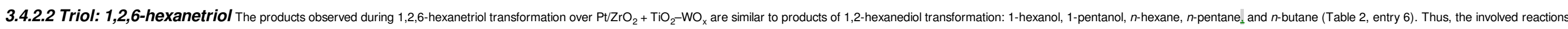

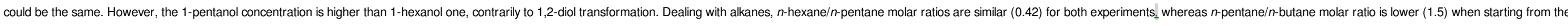
triol.

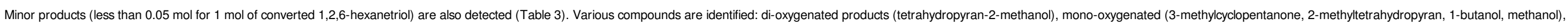
methane, cycloalkane (cyclohexane and methylcyclopentane)], and carboxylic acids (hexanoic, pentanoic, propanoic).

Table 3 Minor products observed during the transformation of 1,2,6-hexanetriol over $\mathrm{Pt}_{2} / \mathrm{ZrO}_{2}+\mathrm{TiO}_{2}-\mathrm{WO}_{\mathrm{x}}$.

\begin{tabular}{|c|c|c|}
\hline Category & Compound & Yield* $\left(\mathrm{mol} \mathrm{mol}_{\text {nexanetriol }}{ }^{-1}\right)$ \\
\hline \multirow[t]{3}{*}{ Heterocycle } & Tetrahydropyran-2-methanol & 0.018 \\
\hline & 2-methyltetrahydropyran & 0.001 \\
\hline & tetrahydropyran & 0.043 \\
\hline Ketone & 3-Methylcyclopentanone & 0.017 \\
\hline \multirow[t]{2}{*}{ Alcohols } & 1-Butanol & 0.019 \\
\hline & methanol** & 0.009 \\
\hline \multirow[t]{2}{*}{ Cycloalkanes } & Cyclohexane & 0.003 \\
\hline & Methylcyclopentane & 0.002 \\
\hline Alkane & Methane & 0.001 \\
\hline \multirow[t]{3}{*}{ Acids } & Hexanoic acid & 0.007 \\
\hline & Pentanoic acid & 0.017 \\
\hline & Propionic acid & 0.006 \\
\hline
\end{tabular}


Operating conditions: $240^{\circ} \mathrm{C}, 37 \mathrm{bar}$, WHSV $=2 \mathrm{~h}^{-1}$

* The yields are given as indications. The amount of each compound is too low for a proper quantification.

** Methanol may come from the cleaning procedure of the GC-FID.

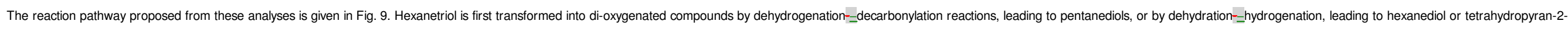
methanol. The latter can undergo dehydration-hydrogenation and form methyl-tetrahydropyran, or decarbonylation, leading to tetrahydropyran.

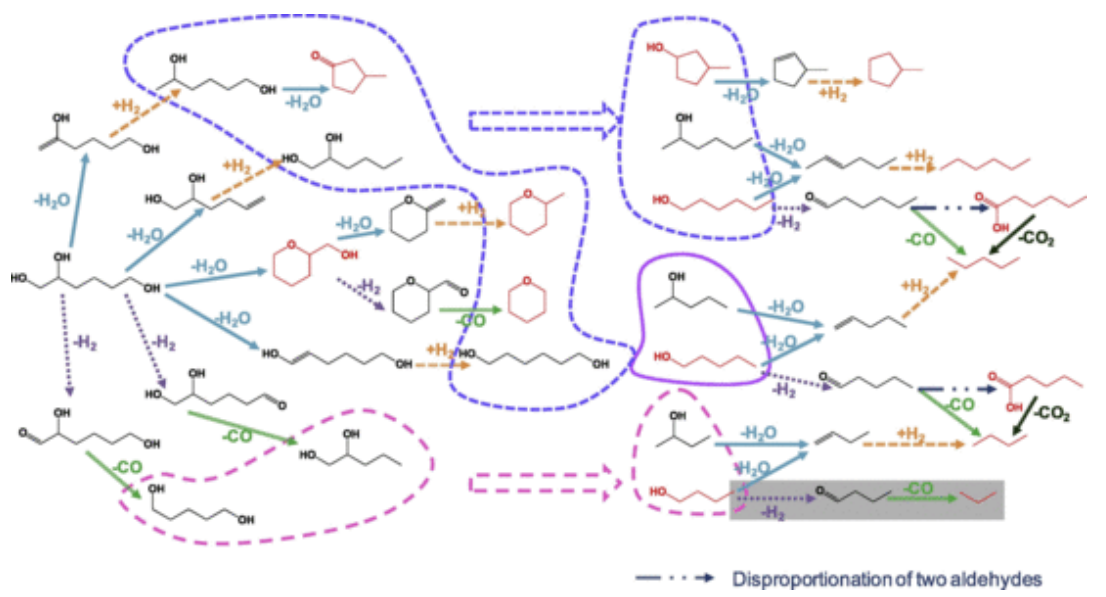

Fig. 9 Reaction scheme of $1,2,6$-hexanetriol transformation over $\mathrm{Pt} / 2 \mathrm{rO}_{2}+\mathrm{TiO}_{2}-\mathrm{WO}_{\mathrm{x}}$

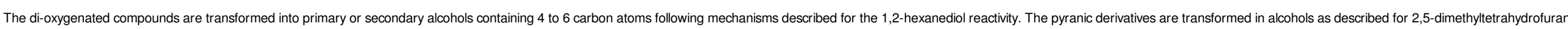

Finally, the mono-alcohols intermediates can give alkanes by dehydration-_hydrogenation or by dehydrogenation_-_decarboxylation, as discussed earlier.

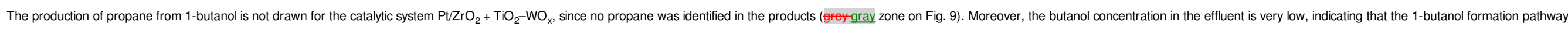
is minor and thus that the first step of 1,2,6-hexanetriol transformation is preferentially a dehydration reaction.

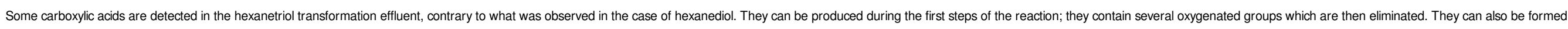

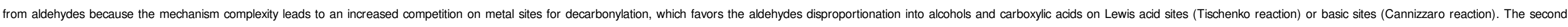
hypothesis is presented ein Fig. 9.

One can note that methanol and methane were detected in 1,2,6-hexanetriol transformation products. These $\mathrm{C} 1$ compounds are assumed to be formed from $\mathrm{CO}_{\text {or }} \mathrm{CO}_{2}$ by reduction or methanation reactions, as suggested in part 3.2 .

\section{Discussion}

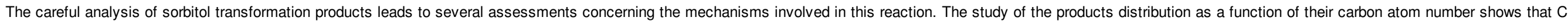

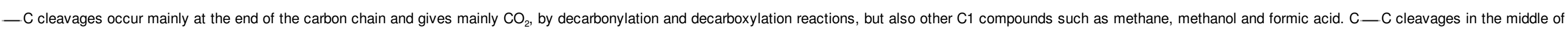
the carbon chain with retro-aldol reactions occur too but are minor.

The oxygen distribution revealed that the successive deoxygenation reactions have different reaction rates. Isosorbide and mono-oxygenated conversions were identified as the slowest reactions.

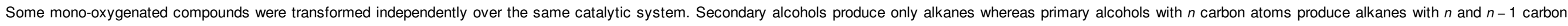

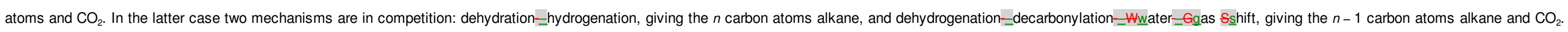




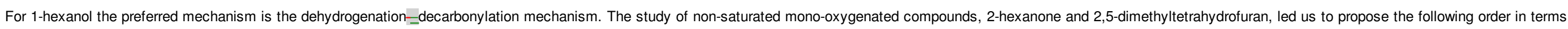
of increasing reactivity: $\mathrm{C}-\mathrm{O}-\mathrm{C} \sim \mathrm{C}=\mathrm{O}<\mathrm{C}-\mathrm{OH}$.

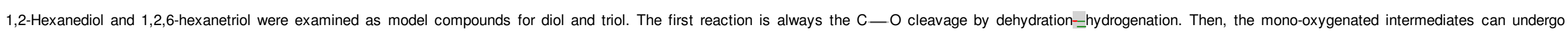
dehydration_-_hydrogenation or dehydrogenation__decarbonylation, leading to hydrocarbons and eventually $\mathrm{CO}_{2}$.

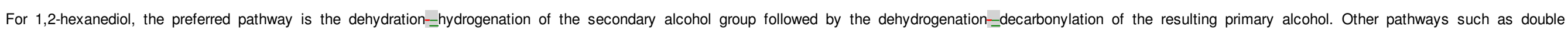
dehydration_-hydrogenation reaction are also present but minor. The distance between acid and metallic sites on the catalyst could disfavor the double dehydration-hydrogenation pathway.

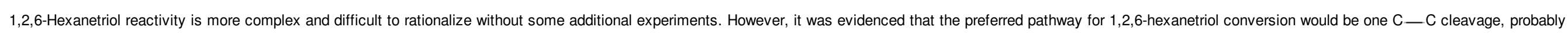

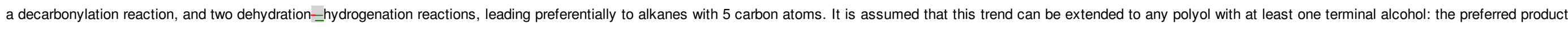
will be the $n-1$ carbon atom alkane.

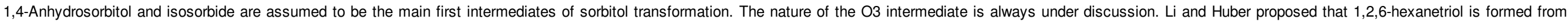

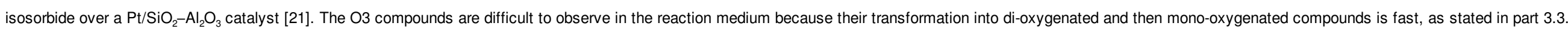

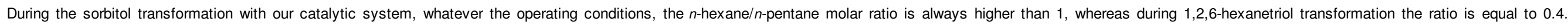
Obviously $y_{1}, 2,6$-hexanetriol is not the only $\mathrm{O} 3$ intermediate contrary to the hypothesis made for the $\mathrm{Pt} / \mathrm{SiO}_{2}-\mathrm{Al}_{2} \mathrm{O}_{3}$ catalyst.

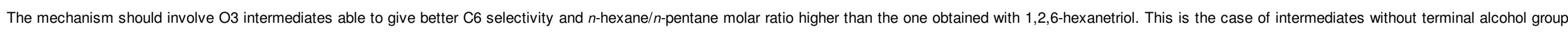
like 2,3,5-hexanetriol and 2,3,4-hexanetriol. Their selectivity is explained by the impossibility to break a $\mathrm{C}-\mathrm{C}$ bond by decarboxylation.

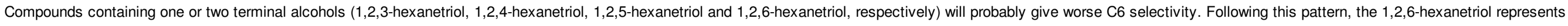
the worst case for $\mathrm{C} 6$ selectivity.

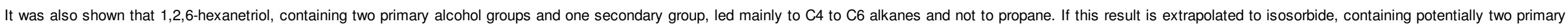

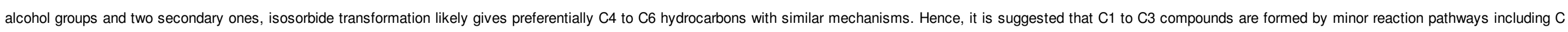

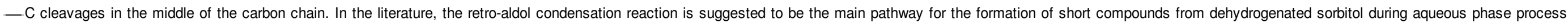
over $\mathrm{Pt} / \mathrm{SiO}_{2}-\mathrm{Al}_{2} \mathrm{O}_{3}$ [22].

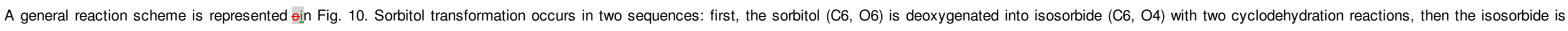
transformed into mono-oxygenates $(\mathrm{C} 4-6, \mathrm{O} 1)$ and hydrocarbons $(\mathrm{C} 4-6, \mathrm{O})$ via dehydration_-hydrogenation, dehydrogenation_-decarbonylation and dehydrogenation_disproportionation_-decarboxylation reactions. 


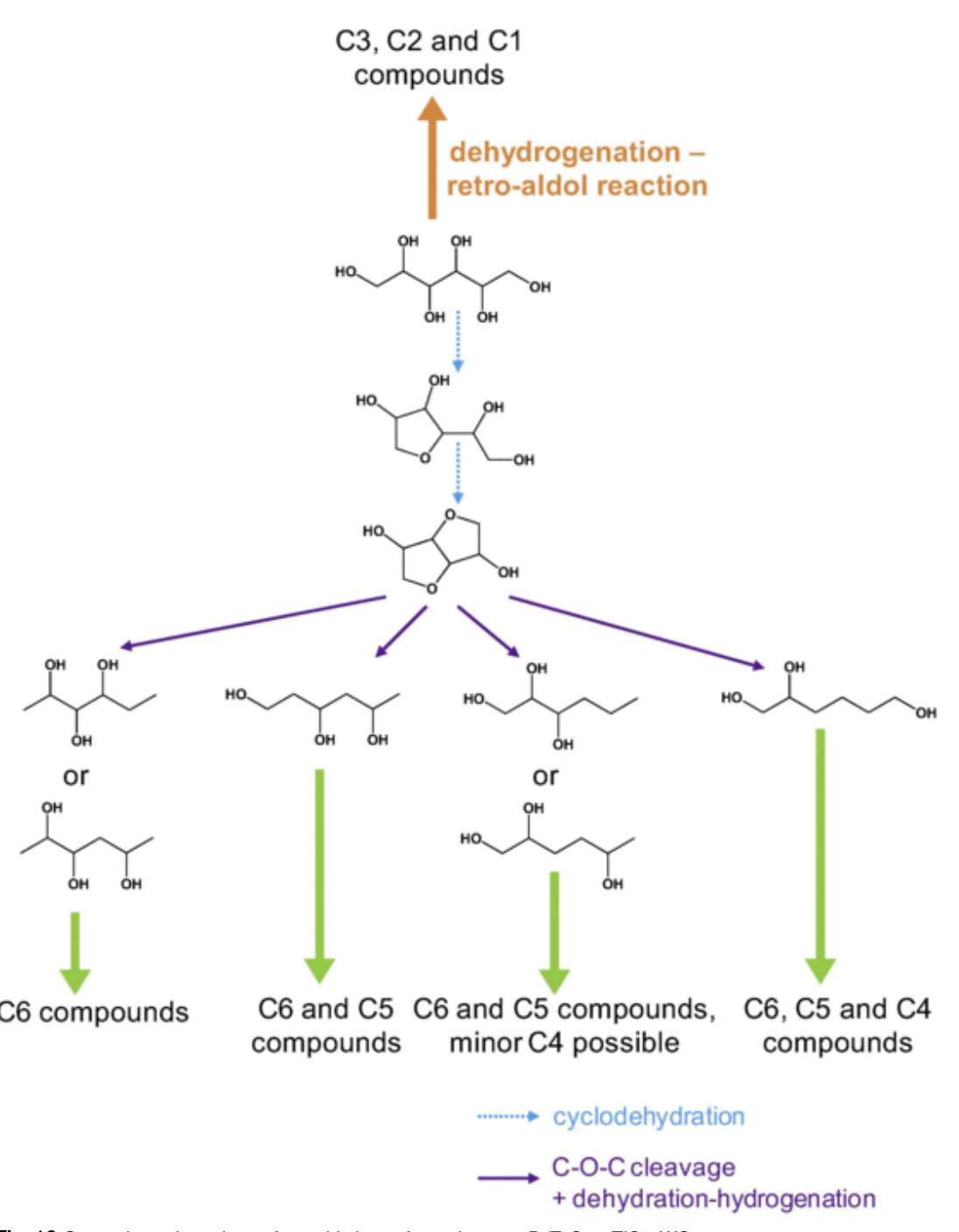

Fig. 10 General reaction scheme for sorbitol transformation over $\mathrm{Pt}_{\mathrm{ZrO}}+\mathrm{TiO}_{2}-\mathrm{WO}_{x}$

According to our study, the selectivity in C6 compounds from sorbitol transformation depends on three main parameters:

(i) the selectivity towards middle_-chain $\mathrm{C}-\mathrm{C}$ cleavage during the early steps of sorbitol transformation;

(ii) the nature of triol formed as intermediate;

(iii) the $\mathrm{C} n-1$ selectivity when a $\mathrm{C} n$ diol or triol is transformed.

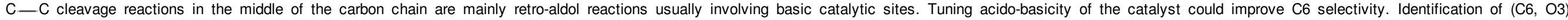

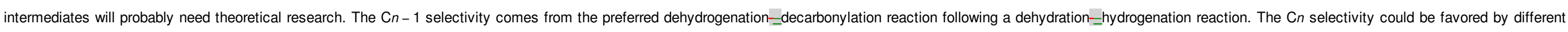

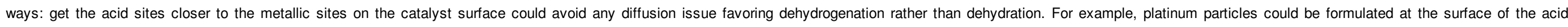




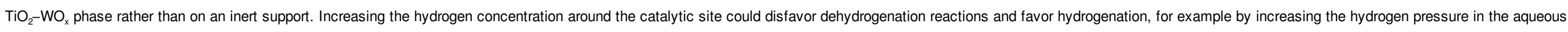

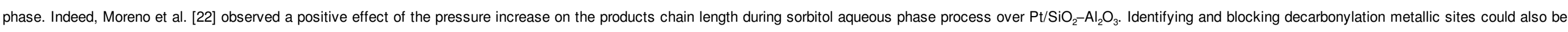
an interesting progress.

\section{Conclusion}

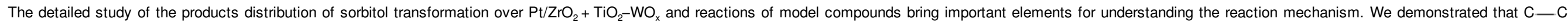

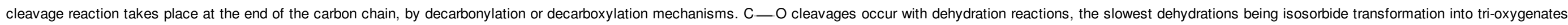
and the mono-alcohols dehydration. The kinetic ranking of $\mathrm{C}-\mathrm{O}$ cleavage reactions, from the fastest to the slowest, is $\mathrm{C}-\mathrm{OH}>\mathrm{C}=\mathrm{O} \sim \mathrm{C}-\mathrm{O}-\mathrm{C}$.

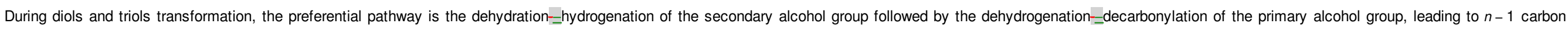
atoms compounds from $\mathrm{C} n$ diols or triols. The proximity of hydrogenation, dehydrogenation and decarbonylation catalytic sites on metal surface can be responsible for this selectivity orientation.

\section{Acknowledgments}

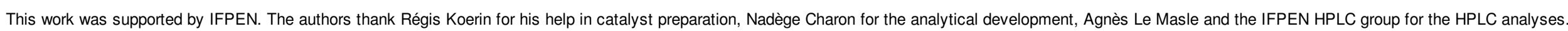

\section{References}

\section{[1]}

World Energy Outlook 2012, IEA (International Energy Agency), Paris, 2012.

[2]

Y.Q. Pu, D.C. Zhang, P.M. Singh and A.J. Ragauskas, Biofuels, Bioprod. Biorefin. 2, 2008, 58.

[3]

C.-H. Zhou, X. Xia, C.-X. Lin, D.-S. Tong and J. Beltramini, Chem. Soc. Rev. 40, 2011, 5588.

[4]

J.J. Verendel, T.L. Church and P.G. Andersson, Synthesis 2011, 1649.

[5]

J. Zhang, J.-B. Li, S.-B. Wu and Y. Liu, Ind. Eng. Chem. Res. 52, 2013, 11799.

[6]

A. Cabiac, E. Guillon, F. Chambon, C. Pinel, F. Rataboul and N. Essayem, Appl. Catal. A Gen. 402, 2011, 1.

[7]

A. Fukuoka and P.L. Dhepe, Angewandte Chem. Int. Ed., 45, 2006, 5161.

[8]

L. Vilcocq, A. Cabiac, C. Especel, E. Guillon and D. Duprez, Oil Gas Sci. Technol. Rev. IFP Energies Nouvelles. 68, 2013, 841.

[9]

G.W. Huber, R.D. Cortright and J.A. Dumesic, Angew. Chem. Int. Ed., 43, 2004, 1549.

[10]

R.R. Davda, J.W. Shabaker, G.W. Huber, R.D. Cortright and J.A. Dumesic, Appl. Catal. B: Environ. 56, 2005, 171 
R. Alcalá, M. Mavrikakis and J.A. Dumesic, J. Catal. 218, 2003, 178.

[12]

K. Murata, I. Takahara and M. Inaba, React. Kinet. Catal. Lett. 93, 2008, 59.

[13]

B. Liu and J. Greeley, J. Phys. Chem. C 115, 2011, 19702.

[14]

A. Wawrzetz, B. Peng, A. Hrabar, A. Jentys, A.A. Lemonidou and J.A. Lercher, J. Catal. 269, 2010, 411.

[15]

K. Wang, M.C. Hawley and T.D. Furney, Ind. Eng. Chem. Res. 34, 1995, 3766.

[16]

C. Montassier, J.C. Ménézo, L.C. Hoang, C. Renaud and J. Barbier, J. Mol. Catal. 70, 1991, 99.

[17]

E.P. Maris and R.J. Davis, J. Catal. 249, 2007, 328.

[18]

F. Auneau, C. Michel, F. Delbecq, C. Pinel and P. Sautet, Chem. Eur. J. 17, 2011, 14288.

[19]

B. Peng, C. Zhao, I. Mejía-Centeno, G.A. Fuentes, A. Jentys and J.A. Lercher, Catal. Today 183, 2012, 3.

[20]

A.V. Kirilin, A.V. Tokarev, E.V. Murzina, L.M. Kustov, J.-P. Mikkola and D.Y. Murzin, ChemSusChem 3, 2010, 708.

[21]

N. Li and G.W. Huber, J. Catal. 270, 2010, 48.

[22]

B.M. Moreno, N. Li, J. Lee, G.W. Huber and M.T. Klein, RSC Adv. 3, 2013, 23769.

[23]

R.D. Cortright, R.R. Davda and J.A. Dumesic, Nature 418, 2002, 964.

[24]

P. Sun, D. Yu, Y. Hu, Z. Tang, J. Xia, H. Li and H. Huang, Korean J. Chem. Eng. 28, $2011,99$.

[25]

L. Vilcocq, A. Cabiac, C. Especel, S. Lacombe, D. Duprez, Catal. Today, 2014 (in press).

[26]

R.M. West, M.H. Tucker, D.J. Braden and J.A. Dumesic, Catal. Commun. 10, 2009, 1743. 
N. Li, G.A. Tompsett and G.W. Huber, ChemSusChem 3, 2010, 1154.

[28]

L. Vilcocq, R. Koerin, A. Cabiac, C. Especel, S. Lacombe and D. Duprez, Appl. Catal. B Environ. 148-149, 2014, 499.

[29]

L. Vilcocq, A. Cabiac, C. Especel, S. Lacombe and D. Duprez, Catal. Today 189, 2012, 117.

[30]

W. Tischtschenko, Chem. Zentralbl. 77, 1906, 1309.

[31]

C. Montassier, D. Giraud, J. Barbier and J.P. Boitiaux, Bull. Soc. Chim. Fr. 2, 1989, 148.

[32]

P.P. Pescarmona, K.P.F. Janssen, C. Delaet, C. Stroobants, K. Houthoofd, A. Philippaerts, C. De Jonghe, J.S. Paul, P.A. Jacobs and B.F. Sels, Green Chem. 12, $2010,1083$.

[33]

F. Aiouache, L. McAleer, Q. Gan, A.a.H. Al-Muhtaseb and M.N. Ahmad, Appl. Catal. A: Gen. 466, 2013, 240.

[34]

F. Gao, R. Li and M. Garland, J. Mol. Catal. A: Chem. 272, 2007, 241.

\section{Graphical abstract}

dehydrogenation dehydration -

retro-aldol reactions hydrogenation reactions

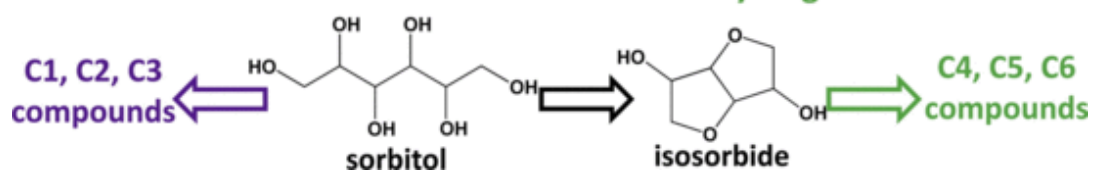

Highlights

- The mixed $\left(\mathrm{PtZrO}_{2}+\mathrm{TiO}_{2}-\mathrm{WO}_{\mathrm{x}}\right)$ solid eatalyses catalyzes sorbitol transformation into liquid alkanes.

- The limiting steps are the isosorbide and mono-oxygenated intermediate transformations.

- $\mathrm{C}-\mathrm{C}$ bond cleavage mainly consists of dehydrogenation-decarbonylation reactions.

- The first reaction from 1,2-hexanediol and 1,2,6-hexanetriol is a $\mathrm{C}$ - O cleavage by dehydration_-hydrogenation.

\section{Queries and Answers}


Query: Please confirm that given name(s) and surname(s) have been identified correctly.

Answer: We confirm that names and surnames are correct

Query: Please check whether the designated corresponding author is correct, and amend if necessary.

Answer: The corresponding author is correct

Query: Please update Ref. [25]

Answer:

\section{[25]}

L. Vilcocq, A. Cabiac, C. Especel, S. Lacombe, D. Duprez, Catal. Today, 2014 (in press, corrected proof). DOI: 10.1016/j.cattod.2014.06.014

Query: Please check the layout of Table 1, and correct if necessary.

Answer: The layout is correct 